\title{
UJI AKTIVITAS SEDIAAN TEH BIJI MAHONI (Swietenia mahagoni ) UNTUK MENURUNKAN KADAR GLUKKOSA DAN AKTIVITAS PEROKSIDASI LIPID PADA TIKUS DIABETES MILLITUS TIPE 2
}

\author{
Nielma Auliah, Muhammad Asri \\ Universitas Megarezky \\ Email : nielmaauliah@gmail.com
}

\begin{abstract}
Penelitian ini bertujuan untuk mengetahui pengaruh pemberian the biji mahoni ( Swietenia mahagoni) terhadap kadar MDA tikus diabetes melitus tipe 2 yang diinduksi aloksan. Dengan menggunakan metode desain control group pretest-post-test dan menggunakan 15 tikus yang dibagi dalam 5 kelompok yaitu kelompok I kelompok negatif, kelompokll kelompok kontrol positif, kelompok III teh biji mahoni $5 \mathrm{gram} / \mathrm{kgBB}$, kelompok IV teh biji mahoni $10 \mathrm{gram} / \mathrm{kgBB}$ dan kelompok V teh biji mahoni $15 \mathrm{gram} / \mathrm{kgBB}$. Perlakuan dilakukan selama 14 hari..Pada penelitian ini menunjukan bahwa kadar glukosa darah berpengaruh terhadap kenaikan kadar MDA. Pada pemberian dosis teh $15 \mathrm{gram} / \mathrm{kgBB}$ menunjukan nilai signifikan terhadap penurunan kadar glukosa darah $\mathrm{P}=0,000<(\alpha 0,05)$ dan kadar MDA darah $\mathrm{P}=$ $0,000<(\alpha$ 0,05 $)$ dan dapat disimpulkan bahwa Teh biji mahoni ( Swietenia mahagoni ) memiliki pengaruh terhadap penurunan kadar MDA tikus diabetes melitus tipe 2 yang diinduksi aloksan, dengan dosis $15 \mathrm{gram} / \mathrm{kg}$ BB yang merupakan dosis optimal dalam menurunkan kadar Glukosa dan Kadar MDA
\end{abstract}

\section{ABSTRACT}

This research aimed to know the effect of mahagony seeds ( Swieteniamahagoni) tea of MDA levels induced type 2 diabetes mellitus alloxan. By using the control group design method, post-test and by using 15 rats divided into 5 groups, namely group I negative group, group II control Alloxan induction, group III tea mahagony seeds $5 \mathrm{gram} / \mathrm{kgBB}$, group IV tea mahagony seeds $10 \mathrm{gram} / \mathrm{kgBB}$ and group $V$ mahagony seeds $15 \mathrm{gram} / \mathrm{kgBB}$. The treatment was carried out for 14 days. In this research showed that the level of blood glucose affects increase of MDA levels. At 15 gram $/ \mathrm{kgBBof}$ tea dosage presentasionshowed a significant value on decreasing blood glucose levels $P=0,000<(\alpha$ $0,05)$ and blood MDA levels $P=0,000<(\alpha, 0,05)$ and it can be concluded that mahogany seed tea (Swieteniamahagoni) had an effect on decreasing levels of rat MDA type 2 diabetes mellitus induced by alloxan, with a dose of 15 grams $1 \mathrm{kgBB}$ which is the optimal dose in reducing blood Glucose and MDA levels.

Keywords : Type 2 Diabetes Mellitus, MDA, Mahogany Seeds Tea, Alloxan

\section{PENDAHULUAN}

Diabetes Melitus (DM) merupakan penyakit berbagai etiologi yang ditandai dengan hiperglikemik dan gangguan metabolik yang ditandai dengan peningkatan kadar glukosa dalam darah kaitannya dengan keadaan abnormalitas karbonhidrat, protein, lemak terjadi karna sekresi insulin (Dipiro et al, 2015 ; Hasan et al 2013). Menurut American Diabetes Association (ADA) 2015, DM dapat diklasifikasikan menjadi beberapa tipe yakni, DM tipe 1, DM tipe 2, DM Gestasional danDM tipe lain, DM tipe 2 merupakan salah satu jenis yang paling banyak di temukan yaitu lebih dari $90-95 \%$. DM tipe 2 ditandai dengan terjadinya hiperglikemia yang dikarenakan adanya penurunan sekresi insulin. Kondisi hiperglikemik juga disebabkan adanya peningkatan produksi radikal bebas atau spesies oksigen reaktif (ROS) (Tiwari et al, 2013). Lipid merupakan target utama ROS. Salah satu produk dekomposisi dari oksidasi lipid adalah malondialdehid (MDA), Peningkatan kadar MDA dipengaruhi oleh meningkatnya produksi ROS (Tiwari et al., 2013 ; Tangvarasittichai et al., 2014). Radikal bebas (ROS) bersifat toksik terhadap sel beta pangkreas karena dapat menyebabkan kerusakan DNA pankreas (Fitriana et al, 2017). Dengan adanya perbaikan pada jaringan pankreas, maka terjadi peningkatan jumlah insulin di dalam tubuh, sehingga glukosa darah akan masuk ke dalam sel sehingga terjadi penurunan glukosa darah dalam tubuh (Tiwari et al., 2013). Mahoni merupakan salah satu tanaman emperis digunakan di Indonesia untuk pengobatan diabetes. Dengan adanya flavonoid pada mahoni (Swietenia mahagoni) dapat meredam aktivitas radikal bebas yang diatasi dengan adanya antioksidan yang berfungsi sebagai agen oksidator sebelum merusak sel sehingga kerusakan sel dapat dikurangi serta dapat menurukan kadar malondialdehid (MDA), serta senyawa Swietenin dalam biji mahoni (Swietenia mahagoni) yang berfungsi 
sebagai agen hipoglikemia (Preedy et al, 2011). biji mahoni mengandung senyawasenyawa yang terdiri dari flavonoid, alkaloid, terpenoid, antraquinon, saponin dan yang terbukti memiliki aktivitas antioksidan. Antioksidan terlibat dalam perbaikan sel yang rusak. Kerusakan sel yang diakibatkan oleh adanya radikal bebas dapat diatasi dengan adanya antioksidan yang berfungsi sebagai agen penurun dan menurunkan oksidator sebelum merusak sel sehingga kerusakan sel dapat dikurangi. Dengan adanya perbaikan pada jaringan pankreas, maka terjadi peningkatan jumlah insulin di dalam tubuh sehingga glukosa darah akan masuk ke dalam sel sehingga terjadi penurunan glukosa darah dalam tubuh (Sumekar dkk,2016). Tujuan dari penelitian mengetahui pengaruh Pemberian teh biji mahoni (Swietenia Mahagoni) terhadap kadar malondialdehid (MDA) tikus diabetes tipe 2 yang diinduksi aloksan serta sebagai obat tradisional untuk penyakit diabetes militus yang relatife aman dengan menggunakan bahan asal tanaman herbal.

\section{METODE}

Penelitian ini adalah penelitan eksperimental dengan menggunakan design control group pre-test-post-test, dimana dilakukan pemeriksan glukosa sebelum dan sesudah perlakuan,serta uji aktivitas kadar glukosa dan aktivitas peroksidasi lipid pada tikus diabetes melitus tipe 2. Dilanjutkan uji statistik dengan uji one way anova, dilaksanakan di laboratorium kimia farmasi Universitas megarezky, laboratorium farmakologi dan instrumen Universitas Muslim Indonesia 2019.

\section{Prosedur Kerja :}

Bahan yang digunakan dalam penelitian ini yaitu air suling, aloksan, asam asetat, biji mahoni (Swietenia mahagoni), es batu,ketamin injeksi, larutan EDTA,Na$\mathrm{CMc}, \mathrm{Na}_{2} \mathrm{SO}_{4}, \mathrm{~N}$ - butanol, strip test glukosa, asam tri-kloroasetat (TCA), asam tiobarbiturat (TBA).

\section{Penyiapan dan Pengolahan Sampel}

a. Pengolahan sampel / simplisia Biji mahoni ( Swietenia Mahoni ) dicuci bersih dengan air mengalir, dikeringkan dengan cara dianginanginkan kemudian disortasi kering dan diserbukkan. b. Pembuatan teh biji mahoni Swietenia Mahoni )

Serbuk biji mahoni ( Swietenia Mahoni ) ditimbang sebanyak $5 \mathrm{~g}$, $10 \mathrm{~g}, 15 \mathrm{~g}$ kemudian di masukan dalam kantong celup kemudian diseduhkan dengan air sebanyak $100 \mathrm{ml}$

2. Pembuatan suspensi Na.CMC $1 \%$

Ditimbang Na.CMC sebanyak 1 gram, kemudian dimasukan kedalam lumpang dilarutkan dalam sebagian aquades hangat, diaduk dan ditambah aquades sambil terus diaduk sampai homogen. Setelah homogen semua sisa aquades ditambahkan sampai didapatkan volume larutan Na.CMC $100 \mathrm{ml}$ dengan memakai labu takar $100 \mathrm{ml}$.

3. Pembuatan larutan natrium sulfat $\mathrm{Na}_{2} \mathrm{SO}_{4}$

Sebanyak 28,408 gram natrium sulfat ditimbang lalu dilarutkan dengan sedikit aquadest, kemudian diencerkan sampai volume larutan menjadi $100 \mathrm{ml}$.

4. Pembuatan larutan TCA $10 \%$

Sebanyak 10 gram asam trikloroasetat ditimbang lalu dilarutkan dengan sedikit aquadest, kemudian diencerkan sampai volume larutan menjadi $100 \mathrm{ml}$ (Dawiyah, 2012 ).

5. Pembuatan larutan TBA $0,2 \%$

Sebanyak 0,2 gram asam tiobabiturat ditimbang lalu dilarutkan dengan sedikit $\mathrm{NA}_{2} \mathrm{SO}_{4}$, kemudian diencerkan sampai volume larutan 100 menjadi $100 \mathrm{ml}$ (Dawiyah, 2012 ) .

6. Pembuatan larutan aloksan monohidrat

Dosis aloksan yang diberikan pada tikus (200 g) yaitu $200 \mathrm{~g} / 1000 \mathrm{~g}$ $x 150 \mathrm{mg} / \mathrm{kg} B B=30 \mathrm{mg} / \mathrm{g}$ BB tikus. Volume pemberian maksimal pada tikus standar yang diinjeksikan secara intraperitonial yaitu $5 \mathrm{~mL}$. Pada penelitian ini, konsentrasi aloksan yang diberikan pada tikus adalah 30 $\mathrm{mg} / 5 \mathrm{~mL}$. Aloksan monohidrat dilarutkan dengan aqua pro injection, kemudian larutan segera diinjeksikan pada tikus (Dawiyah, 2012 ).

\section{Perlakuan}

Dalam penelitian ini digunakan hewan uji tikus putih jantan galur wistar yang berjumlah 15 ekor terdiri 5 
kelompok uji, masing-masing perlakuan terdiri dari 3 ekor tikus.

Kelompok I : kontrol negatif (Na.CMC $1 \%)$

Kelompok II : kontrol positif, (Aloksan $30 \mathrm{mg} / \mathrm{g}$ BB)

Kelompok III : teh biji mahoni $5 \mathrm{~g}$ Kelompok IV : teh biji mahoni $10 \mathrm{~g}$ Kelompok V : teh biji mahoni $15 \mathrm{~g}$

8. Pengukuran Glukosa

Hewan uji diinduksi aloksan monohidrat dengan dosis $30 \mathrm{mg} / \mathrm{g} \mathrm{BB}$, penginduksian dilakukan pada setiap kelompok kecuali kelompok I. Sebelum pemberian aloksan tikus dipuasakan selama 8 jam, dan dilakukan pengukuran kadar glukosa darah sebelum dan pada hari ketiga setelah pemberian aloksan.

9. Pengambilan darah hewan uji

Proses pengambilan darah pada hewan uji tikus( Rattus norvegicus ) dilakukan secara plexus retroorbitalis. Tikus diinjeksi ketamine dengan dosis $25 \mathrm{mg} / 5 \mathrm{ml}$ secara intra peritoneal. Kemudian pipa kapiler digoreskan pada medial canthus mata dibawah bola mata kea rah foramen opticus. Pipa kapiler diputar sampai melukai plexus dan darah di tamping pada tabung sentrifuge yang telah diberi larutan EDTA.

10. Pengukuran kadar Malondialdehid ( MDA )

Darah dikumpulkan dalam tabung sentrifuge yang berisi larutan
EDTA.Sebanyak $0,5 \mathrm{ml}$ darah dimasukan kedalam tabung sentrifuge dan kemudian protein diendapkan dengan menambahkan $2,5 \mathrm{ml}$ asam Trikloroasetat ( TCA ). Setelah itu di sentrifugepada $1000 \mathrm{rpm}$ selama 10 menit kemudian supernatant dipisahkan. Endapan protein disuspensi kembali dalam $2,5 \mathrm{ml}$ asam asetat dan ditambahkan $3 \mathrm{ml}$ asam tiobabiturat ( TBA ), dipanaskan dalam waterbath selama 30 menit, kemudian didinginkan cepat dalam icebath untuk menghentikan reaksi, kemudian di ekstraksi dengan menambahkan $\mathrm{n}$ butanol sebanyak $4 \mathrm{ml}$ dan sentrifuge kembali pada $3000 \mathrm{rpm}$ selama 10 menit. Hasil sentrifuge diukur absorbansinya pada spektrofotometri dengan panjang gelombang $532 \mathrm{~nm}$ (Dawiyah, 2012).

\section{HASIL DAN PEMBAHASAN}

Teh biji mahoni diperoleh dengan cara menyeduh serbuk biji mahoni dengan varian dosis 5 gram, $10 \mathrm{gram}$ dan $15 \mathrm{gram}$ dalam $100 \mathrm{ml}$ air panas. Pertama-tama biji mahoni di keringkan dan setelah itu di serbukkan menggunakan blender, yang kemudian disaring menggunakan mesh hingga menjadi serbuk halus. Hasil saringan di timbang sesuai dengan dosis dan dimasukan kedalam kantong celup yang kemudian diseduh dengan $100 \mathrm{ml}$ air panas.

Tabel 1. Hasil Pengukuran Kadar Glukosa Darah Tikus

\begin{tabular}{cccccc}
\hline Perlakuan & $\begin{array}{c}\text { Tikus } \\
\text { No }\end{array}$ & $\begin{array}{c}\text { BB } \\
\text { (gram })\end{array}$ & H-0 mg/dl & H-3 mg/dl & H-14 mg/dl \\
& 1 & $180 \mathrm{~g}$ & 90 & 90 & 100 \\
Kontrol negatif Na cmc 1 & 2 & $185 \mathrm{~g}$ & 92 & 90 & 111 \\
$\%$ & 3 & $180 \mathrm{~g}$ & 89 & 92 & 101 \\
Nilai rata-rata & & 181,66 & 90,33 & 90,66 & 104 \\
Kontrol positif induksi & 1 & $171 \mathrm{~g}$ & 80 & 270 & 323 \\
aloksan & 2 & $194 \mathrm{~g}$ & 78 & 308 & 321 \\
Nilai rata-rata & 3 & $176 \mathrm{~g}$ & 74 & 266 & 300 \\
P1 & 1 & 176,66 & 77,33 & 281,33 & 314,66 \\
Teh biji mahoni 5 gram & 2 & $192 \mathrm{~g}$ & 81 & 272 & 170 \\
& 3 & $187 \mathrm{~g}$ & 70 & 250 & 179 \\
& $177 \mathrm{~g}$ & 73 & 283 & 194 \\
\hline
\end{tabular}




\begin{tabular}{cccccc}
\hline Nilai rata-rata & & 185,33 & 74,66 & 268,33 & 181 \\
P2 & 1 & $176 \mathrm{~g}$ & 71 & 233 & 127 \\
Teh biji mahoni 10 gram & 2 & $188 \mathrm{~g}$ & 75 & 242 & 131 \\
& 3 & $180 \mathrm{~g}$ & 90 & 283 & 140 \\
Nilai rata-rata & & 181,33 & 78,66 & 252,66 & 128,33 \\
P3 & 1 & $184 \mathrm{~g}$ & 97 & 268 & 92 \\
Teh biji mahoni 15 gram & 2 & $190 \mathrm{~g}$ & 88 & 300 & 90 \\
& 3 & $195 \mathrm{~g}$ & 93 & 255 & 94 \\
Nilai rata-rata & & 189,66 & 92,16 & 274,33 & 92 \\
\hline
\end{tabular}

Keterangan :

1. Nilai Kadar glukosa normal yaitu $<100 \mathrm{mg} / \mathrm{dl}$

2. Nilai Kadar glukosa darah yaitu $>200 \mathrm{mg} / \mathrm{dl}$

Tabel 3. Hasil Pengukuran Kadar MDA Awal dan Akhir

\begin{tabular}{|c|c|c|c|c|}
\hline Perlakuan & $\begin{array}{l}\text { Tikus } \\
\text { No }\end{array}$ & $\begin{array}{c}\mathrm{BB} \\
\text { (gram ) }\end{array}$ & $\begin{array}{c}\text { Kadar MDA awal } \\
(\mathrm{nmol} / \mathrm{l})\end{array}$ & $\begin{array}{c}\text { Kadar MDA akhir } \\
(\mathrm{nmol} / \mathrm{l})\end{array}$ \\
\hline \multirow{3}{*}{$\underset{\%}{\text { Kontrol negatif }} \mathrm{Na} \mathrm{cmc} 1$} & 1 & $180 \mathrm{~g}$ & 0,105 & 0,126 \\
\hline & 2 & $185 \mathrm{~g}$ & 0,102 & 0,129 \\
\hline & 3 & $180 \mathrm{~g}$ & 0,106 & 0,127 \\
\hline \multirow[t]{2}{*}{ Nilai rata-rata } & & 181,66 & 0,104 & 0,127 \\
\hline & 1 & $171 \mathrm{~g}$ & 0,111 & 1,910 \\
\hline \multirow{2}{*}{$\begin{array}{l}\text { Kontrol positif induksi } \\
\text { aloksan }\end{array}$} & 2 & $183 \mathrm{~g}$ & 0,118 & 1,905 \\
\hline & 3 & $176 \mathrm{~g}$ & 0,107 & 1,897 \\
\hline Nilai rata-rata & & 176,66 & 0,112 & 1,904 \\
\hline \multirow{3}{*}{$\begin{array}{c}\mathrm{P} 1 \\
\text { Teh biji mahoni } 5 \text { gram }\end{array}$} & 1 & $192 \mathrm{~g}$ & 0,102 & 0,597 \\
\hline & 2 & $187 \mathrm{~g}$ & 0,108 & 0,660 \\
\hline & 3 & $177 \mathrm{~g}$ & 0,105 & 0,669 \\
\hline \multicolumn{2}{|l|}{ Nilai rata-rata } & 185,33 & 0,105 & 0,642 \\
\hline \multirow{3}{*}{$\begin{array}{c}\text { P2 } \\
\text { Teh biji mahoni } 10 \text { gran }\end{array}$} & 1 & $176 \mathrm{~g}$ & 0,107 & 0,385 \\
\hline & 2 & $188 \mathrm{~g}$ & 0,101 & 0,390 \\
\hline & 3 & $180 \mathrm{~g}$ & 0,110 & 0,424 \\
\hline \multicolumn{2}{|l|}{ Nilai rata-rata } & 181,33 & 0,106 & 0,400 \\
\hline \multirow{3}{*}{$\begin{array}{c}\text { P3 } \\
\text { Teh biji mahoni } 15 \text { gram }\end{array}$} & 1 & $184 \mathrm{~g}$ & 0,103 & 0,107 \\
\hline & 2 & $190 \mathrm{~g}$ & 0,106 & 0,111 \\
\hline & 3 & $195 \mathrm{~g}$ & 0,109 & 0,110 \\
\hline Nilai rata-rata & & 189,66 & 0,106 & 0,109 \\
\hline
\end{tabular}

Keterangan :

1. Nilai kosentrasi normal kadar MDA yaitu $0-1 \mathrm{nmol} / \mathrm{l}$ 


\section{Gambar 1. Diagram Kadar Glukosa}

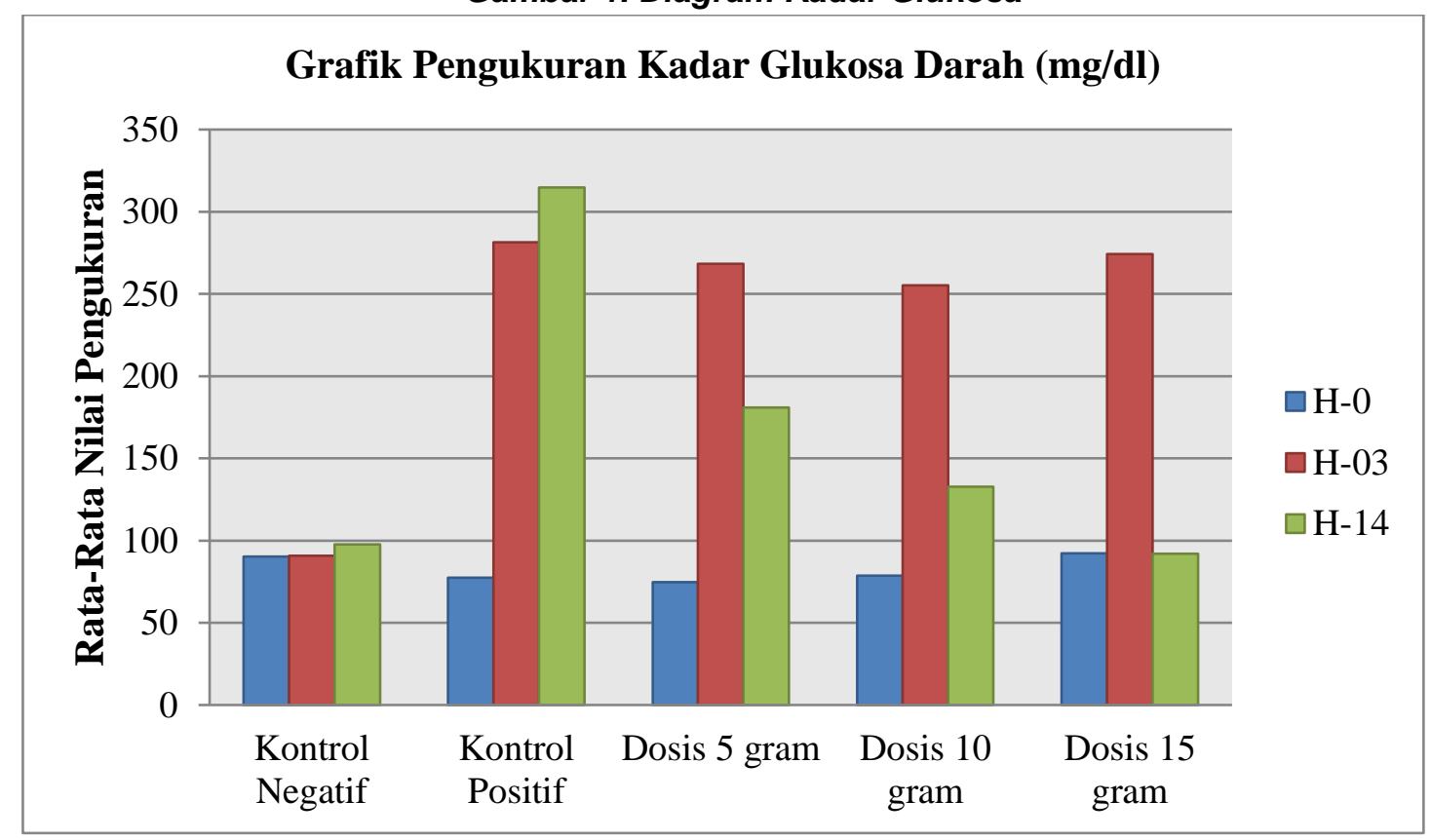

Gambar 2. Diagram Kadar MDA Awal dan Akhir

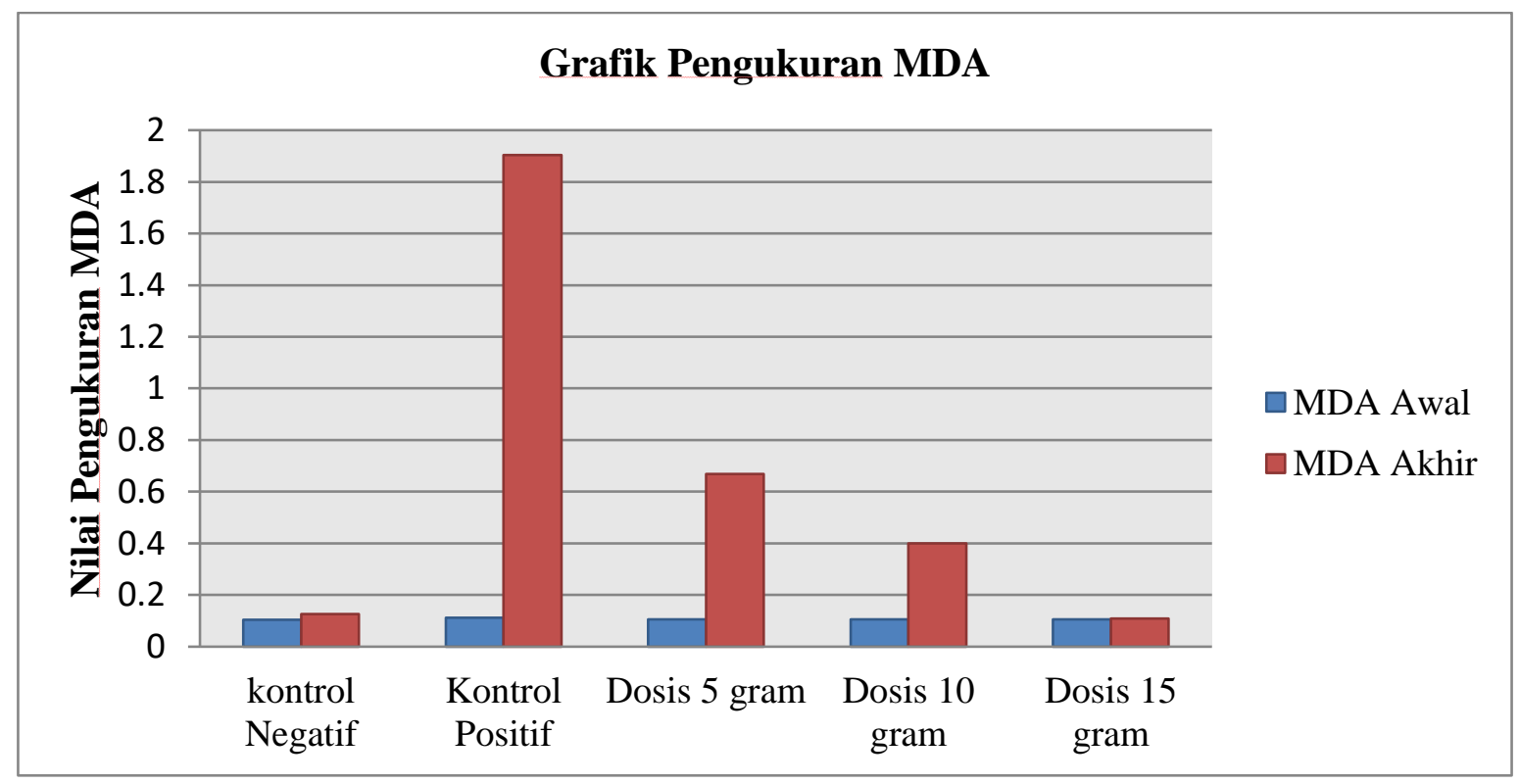

Pada Penelitian ini digunakan 15 ekor tikus putih yang berkelamin jantan, karena sistem hormonalnya lebih stabil dibandingkan tikus betina, walaupun demikian faktor biologis dari hewan uji tidak dapat dihilangkan sehingga dapat mempengharui hasil penelitian oleh karena itu terdapat perbedaan kosentrasi darah awal untuk tiap hewan coba. Pada penelitan ini hewan coba dibagi menjadi 5 kelompok yaitu kelompok pertama, kontrol negatif pemberian Na-CMC. Kelompok kedua, kontrol positif, penginduksian aloksan. Kelompok ketiga tikus diberi teh biji mahoni dengan dosis 5 gram. Kelompok keempat tikus diberi teh biji mahoni dengan 
dosis 10 gram dan kelompok kelima tikus diberi teh biji mahoni dengan dosis 15 gram. Sebelum perlakuan tikus putih jantan dipuasakan terlebih dahulu selama \pm 8 jam untuk meminimalkan pengaruh makanan pada pengukuran kadar glukosa dan MDA awal.

Pemberian aloksan pada tikus putih jantan dilakukan $1 \times 24$ jam sebelum perlakuan dengan tujuan untuk menaikkan kadar glukosa darah tikus putih jantan.Aloksan bekerja dengan cara merusak sel-sel beta pankreas sehingga akan mengalami kerusakan sel. Ini dapat menyebabkan permeabilitas sel meningkat sehingga kerja insulin terganggu yang menyebabkan diabetes melitus. Pengukuran kenaikan kadar glukosa di lakukan pada hari 3 setelah pemberian aloksan. Diabetes melitus dapat juga ditandai dengan meningkatnya kadar radikal bebas di dalam tubuh.

Pada penelitian ini dilakukan Pengukuran kadar MDA, karena MDA digunakan sebagai indikator adanya peningkatan kadar radikal bebas di dalam tubuh. Dimana radikal bebas menyebabkan terjadinya stres oksidatif yang menyebabkan kerusakan pada sel-sel, salah satunya yaitu sel beta pankreas. Makin tinggi absorbansi MDA menunjukan besarnya aktifitas radikal bebas dan rendahnya aktifitas antioksidan. Absorbansi MDA diukur dengan metode spektrofotometri uv-vis. Metode ini merupakan metode yang palinng banyak digunakan untuk mengukur keberadaan radikal bebas dan peroksidasi lipid, mempunyai kepekaan yang cukup tinggi, mudah diaplikasikan untuk berbagai sampel. Metode ini didasarkan pada reaksi antara MDA dengan TBA berwarna merah muda kemudian diukur pada spektrofotometri dengan panjang gelombang $532 \mathrm{~nm}$. MDA merupakan hasil akhir dari peroksidasi lipid, yang bersifat toksik, sehingga pemberian antioksidan sangat diperlukan (Hartono, Bambang, Dachlan, 2017).

Obat diabetes dapat berasal dari bahan alam seperti yang digunakan dalam penelitian ini yaitu biji mahoni yang merupakan antioksidan yang berasal dari alam. Kandungan kimia dari biji mahoni yaitu senyawa swietenin yang dapat menurunkan kadar glukosa darah dan flavanoid yang berperan sebagai antioksidan, mampu menghambbat reaksi oskidasi melalui mekanisme penangkapan radikal bebas dengan menyumbangkan satu elektron pada elektron yang tidak berpasangan dalam radikal bebas sehingga banyaknya radikal bebas jadi berkurang (Hartono dkk, 2019).

Berdasarkan hasil penelitian yang telah dilakukan, pada kelompok pertama kontrol negatif, tikus pertama mempunyai kadar glukosa darah awal $90 \mathrm{mg} / \mathrm{dl}$ sedangkan kadar MDA awalnya yaitu 0,105 , setelah $\mathrm{H}-3$ kadar glukosanya masih sama yaitu $90 \mathrm{mg} / \mathrm{dl}$. Setelah pemberian $\mathrm{Na}$ CMC kadar glukosa darah pada $\mathrm{H}-14$ menjadi $100 \mathrm{mg} / \mathrm{dl}$ dan kadar MDA akhir menajdi 0,126 . tikus kedua mempunyai kadar glukosa darah awal $92 \mathrm{mg} / \mathrm{dl}$ sedangkan kadar MDA awalnya yaitu 0,102 , setelah $\mathrm{H}-3$ kadar glukosanya 90 $\mathrm{mg} / \mathrm{dl}$. Setelah pemberian $\mathrm{Na} \mathrm{CMC}$ kadar glukosa darah pada $\mathrm{H}-14$ menjadi 111 $\mathrm{mg} / \mathrm{dl}$ dan kadar MDA akhir menajdi 0,129. tikus ketiga mempunyai kadar glukosa darah awal $89 \mathrm{mg} / \mathrm{dl}$ sedangkan kadar MDA awalnya yaitu 0,106 , setelah $\mathrm{H}-3$ kadar glukosanya yaitu $92 \mathrm{mg} / \mathrm{dl}$. Setelah pemberian $\mathrm{Na}$ CMC kadar glukosa darah pada $\mathrm{H}-14$ menjadi $101 \mathrm{mg} / \mathrm{dl}$ dan kadar MDA akhir menajdi 0,127.

Pada kelompok kedua kontrol positif, tikus pertama mempunyai kadar glukosa darah awal $80 \mathrm{mg} / \mathrm{dl}$ sedangkan kadar MDA awalnya yaitu 0,111 , setelah 3 hari diinduksi aloksan kadar glukosa darah naik menjadi $270 \mathrm{mg} / \mathrm{dl}$. Setelah $\mathrm{H}-14$ tanpa diberi perlakuan menjadi $323 \mathrm{mg} / \mathrm{dl}$ dan kadar MDA akhir menajdi 1,910. tikus kedua mempunyai kadar glukosa darah awal $78 \mathrm{mg} / \mathrm{dl}$ sedangkan kadar MDA awalnya yaitu 0,118 , setelah 3 hari diinduksi aloksan kadar glukosa darah naik menjadi $308 \mathrm{mg} / \mathrm{dl}$. Setelah $\mathrm{H}-14$ tanpa diberi perlakuan menjadi $321 \mathrm{mg} / \mathrm{dl}$ dan kadar MDA akhir menajdi 1,905. tikus ketiga mempunyai kadar glukosa darah awal $74 \mathrm{mg} / \mathrm{dl}$ sedangkan kadar MDA awalnya yaitu 0,107 , setelah 3 hari diinduksi aloksan kadar glukosa darah naik menjadi $266 \mathrm{mg} / \mathrm{dl}$. Setelah $\mathrm{H}-14$ tanpa diberi perlakuan menjadi $300 \mathrm{mg} / \mathrm{dl}$ dan kadar MDA akhir menajdi 1,897.

Pada kelompok teh biji mahoni 5 gram, tikus pertama mempunyai kadar glukosa darah awal $81 \mathrm{mg} / \mathrm{dl}$ sedangkan kadar MDA awalnya yaitu 0,102, setelah 3 hari diinduksi aloksan kadar glukosa darah naik menjadi $272 \mathrm{mg} / \mathrm{dl}$. Setelah pemberian perlakuan kadar glukosa darah pada $\mathrm{H}-14$ 
menjadi $170 \mathrm{mg} / \mathrm{dl}$ dan kadar MDA akhir menajdi 0,597. tikus kedua mempunyai kadar glukosa darah awal $70 \mathrm{mg} / \mathrm{dl}$ sedangkan kadar MDA awalnya yaitu 0,108 , setelah 3 hari diinduksi aloksan kadar glukosa darah naik menjadi 250 $\mathrm{mg} / \mathrm{dl}$. Setelah pemberian perlakuan kadar glukosa darah pada $\mathrm{H}-14$ menjadi 179 $\mathrm{mg} / \mathrm{dl}$ dan kadar MDA akhir menajdi 0,660. tikus ketiga mempunyai kadar glukosa darah awal $73 \mathrm{mg} / \mathrm{dl}$ sedangkan kadar MDA awalnya yaitu 0,105 , setelah 3 hari diinduksi aloksan kadar glukosa darah naik menjadi $283 \mathrm{mg} / \mathrm{dl}$. Setelah pemberian perlakuan kadar glukosa darah pada $\mathrm{H}-11$ menjadi $194 \mathrm{mg} / \mathrm{dl}$ dan kadar MDA akhir menjadi 0,669

Pada kelompok teh biji mahoni 10 gram, tikus pertama mempunyai kadar glukosa darah awal $71 \mathrm{mg} / \mathrm{dl}$ sedangkan kadar MDA awalnya yaitu 0,107 , setelah 3 hari diinduksi aloksan kadar glukosa darah naik menjadi $233 \mathrm{mg} / \mathrm{dl}$. Setelah pemberian perlakuan kadar glukosa darah pada $\mathrm{H}-14$ menjadi $127 \mathrm{mg} / \mathrm{dl}$ dan kadar MDA akhir menajdi 0,385 . tikus kedua mempunyai kadar glukosa darah awal $75 \mathrm{mg} / \mathrm{dl}$ sedangkan kadar MDA awalnya yaitu 0,101 , setelah 3 hari diinduksi aloksan kadar glukosa darah naik menjadi 242 $\mathrm{mg} / \mathrm{dl}$. Setelah pemberian perlakuan kadar glukosa darah pada $\mathrm{H}-14$ menjadi 118 $\mathrm{mg} / \mathrm{dl}$ dan kadar MDA akhir menajdi 0,390. tikus ketiga mempunyai kadar glukosa darah awal $90 \mathrm{mg} / \mathrm{dl}$ sedangkan kadar MDA awalnya yaitu 0,110 , setelah 3 hari diinduksi aloksan kadar glukosa darah naik menjadi $283 \mathrm{mg} / \mathrm{dl}$. Setelah pemberian perlakuan kadar glukosa darah pada $\mathrm{H}-11$ menjadi $140 \mathrm{mg} / \mathrm{dl}$ dan kadar MDA akhir menajdi 0,424

Pada kelompok teh biji mahoni 15 gram, tikus pertama mempunyai kadar glukosa darah awal $97 \mathrm{mg} / \mathrm{dl}$ sedangkan kadar MDA awalnya yaitu 0,103, setelah 3 hari diinduksi aloksan kadar glukosa darah naik menjadi $268 \mathrm{mg} / \mathrm{dl}$. Setelah pemberian perlakuan kadar glukosa darah pada $\mathrm{H}-14$ menjadi $92 \mathrm{mg} / \mathrm{dl}$ dan kadar MDA akhir menajdi 0,107 . tikus kedua mempunyai kadar glukosa darah awal $88 \mathrm{mg} / \mathrm{dl}$ sedangkan kadar MDA awalnya yaitu 0,106 , setelah 3 hari diinduksi aloksan kadar glukosa darah naik menjadi 300 $\mathrm{mg} / \mathrm{dl}$. Setelah pemberian perlakuan kadar glukosa darah pada $\mathrm{H}-14$ menjadi $90 \mathrm{mg} / \mathrm{dl}$ dan kadar MDA akhir menjadi 0,111. tikus ketiga mempunyai kadar glukosa darah awal $93 \mathrm{mg} / \mathrm{dl}$ sedangkan kadar MDA awalnya yaitu 0,109 , setelah 3 hari diinduksi aloksan kadar glukosa darah naik menjadi $255 \mathrm{mg} / \mathrm{dl}$. Setelah pemberian perlakuan kadar glukosa darah pada $\mathrm{H}-11$ menjadi $92 \mathrm{mg} / \mathrm{dl}$ dan kadar MDA akhir menajdi 0,110

Berdasarkan hasil pengukuran kadar glukosa darah dan kadar MDA pada kelima kelompok perlakuan. Terlihat variasi kenaikan dan penurunan kadar glukosa darah dan kadar MDA pada $\mathrm{H}-0, \mathrm{H}-3$ dan $\mathrm{H}-14$. Pada kelompok negatif yang diberi $\mathrm{Na}$ CMC terjadi sedikit kenaikan glukosa darah dan MDA. Pada kontrol positif yang hanya diberikan induksi aloksan menunjukan kenaikan secara signifikan kadar glukosa darah dan kadar MDA hal ini bisa membuktikan makin tinggi kadar glukosa darah maka makin tinggi pula kadar MDA yang dihasilkan oleh radikal bebas dan pada kelompok yang diberikan teh biji mahoni menunjukan penuunan kadar glukosa darah dan MDA tikus dan yang paling berefek menurunkan adalah teh biji mahoni dengan dosis 15 gam. Penurunan yang terjadi pada kelompok teh biji mahoni terjadi karena teh biji mahoni mengandung senyawa swietenin dan flavanoid, alkaloid, terpenoin yang bersifat antioksidan( Preedy et al, 2011, Sumekar dkk,2016) dengan cara mengoksidasi radikal bebas sehingga melindungi molekul lain dalam sel dari kerusakan akibat oksidasi dari radikal bebas atau oksigen reaktif ( Werdhasri,Asri,2014 )

Uji statatistik data Test of Homogeneity of Variances. Uji ini menggunakan levene test pada kelima kelompok perlakuan, hasilnya pada pengukuran kadar glukosa darah $\mathrm{H}-0$ yaitu glukosa darah awal adalah 0,062, pada pengukuran kadar glukosa darah $\mathrm{H}-3$ yaitu post aloksan adalah 0,084 dan pada hari ke 14 atau glukosa akhir adalah 0,104. Pada analisis menggunakan levene test ini data dikatakan homogen jika menunjukan nilai $p$ $=0,104>\alpha=0,05$ sehingga data Kadar glukosa dikatakan homogeny 
Tabel 5. UJi Statistik Anova Kadar Glukosa Darah

\begin{tabular}{|c|c|c|c|c|c|c|}
\hline & & $\begin{array}{l}\text { Sum of } \\
\text { Squares }\end{array}$ & Df & Mean Square & $\mathrm{F}$ & Sig. \\
\hline $\mathrm{HO}$ & Between Groups & 801.600 & 4 & 200.400 & 6.085 & 0.010 \\
\hline & Within Groups & 329.333 & 10 & 32.933 & & \\
\hline & Total & 1130.933 & 14 & & & \\
\hline $\mathrm{H} 3$ & Between Groups & 94004.267 & 4 & 23501.067 & 169.887 & 0.000 \\
\hline & Within Groups & 1383.333 & 10 & 138.333 & & \\
\hline & Total & 95387.600 & 14 & & & \\
\hline $\mathrm{H} 14$ & Between Groups & 98254.400 & 4 & 24563.600 & 311.194 & 0.000 \\
\hline & Within Groups & 789.333 & 10 & 78.933 & & \\
\hline & Total & 99043.733 & 14 & & & \\
\hline $\begin{array}{l}\text { menggun } \\
\text { hasilnya } \\
\text { darah } \mathrm{H}-\mathrm{c} \\
0,010, \mathrm{p} \\
\text { darah H-- } \\
\text { dan pad } \\
\text { adalah } 0 \\
\text { data dibi } \\
\text { data p } \\
\text { dikatakan } \\
\text { perbedaa } \\
\text { kelompok }\end{array}$ & $\begin{array}{l}\text { ji statatistik an } \\
\text { akan kelima kelom } \\
\text { pada pengukuran } \\
0 \text { yaitu glukosa dar } \\
\text { ada pengukuran } \\
3 \text { yaitu post aloksa } \\
\text { a hari ke } 14 \text { atau } \\
\text {,000. Pada analis } \\
\text { ilang signifikan jik } \\
=0.000<a= \\
\text { data signifikar } \\
\text { in bermakna }\end{array}$ & $\begin{array}{l}\text { a. Uji ini } \\
\text { k perlakuan, } \\
\text { dar glukosa } \\
\text { awal adalah } \\
\text { dar glukosa } \\
\text { adalah } 0,000 \\
\text { lukosa akhir } \\
\text { data anova } \\
\text { menunjukan } \\
5 \text { sehingga } \\
\text { menunjukan } \\
\text { da setiap }\end{array}$ & & $\begin{array}{l}\text { Uji state } \\
\text { omogeneity of } \\
\text { enggunakan le } \\
\text { elima kelompok } \\
\text { engukuran kadar } \\
\text { an pengukuran } \\
\text { 08. Pada analis } \\
\text { st ini data d } \\
\text { enunjukan nilai } \\
\text { hingga data } \\
\text { omogeny }\end{array}$ & $\begin{array}{l}\text { tik data } \\
\text { Variances. } \\
\text { ne test pa } \\
\text { rlakuan, has } \\
\text { IDA awal ac } \\
\text { dar MDA al } \\
\text { menggunal } \\
\text { atakan hom } \\
=0.08> \\
\text { dar MDA }\end{array}$ & $\begin{array}{l}\text { Test of } \\
\text { Uji ini } \\
\text { la kelima } \\
\text { Inya pada } \\
\text { alah } 0,502 \\
\text { hir adalah } \\
\text { an levene } \\
\text { ogen jika } \\
\begin{array}{l}0,05 \\
\text { dikatakan }\end{array}\end{array}$ \\
\hline Tabel 7. & lit Ctotintio An & dar MDA & & & & \\
\hline & & $\begin{array}{c}\text { Sum of } \\
\text { Squares }\end{array}$ & $\mathrm{Df}$ & Mean Square & $\mathrm{F}$ & Sig. \\
\hline Mawal & Between Groups & .000 & & .00 & 1.895 & 0.188 \\
\hline & Within Groups & .000 & 10 & $.00 c$ & & \\
\hline & Total & .000 & 14 & & & \\
\hline Makhir & Between Groups & 6.599 & & 1.65 & 4045.792 & 0.000 \\
\hline & Within Groups & .004 & 10 & .000 & & \\
\hline & Total & 6.604 & 14 & & & \\
\hline
\end{tabular}

Uji statatistik data Anova. Uji ini menggunakan kelima kelompok perlakuan, hasilnya pada pengukuran kadar MDA awal adalah 0,188 dan pengukuran kadar MDA akhir adalah 0,000. Pada analisis menggunakan anova dikatakan signifikan jika data menunjukan nilai $p=0.000<\alpha=$ 0,05 sehingga data Kadar MDA dikatakan data signifikan menunjukan perbedaan bermakna.

\section{KESIMPULAN}

Teh biji mahoni ( Swietenia mahagoni ) memiliki pengaruh terhadap penurunan kadar MDA tikus diabetes melitus tipe 2 yang diinduksi aloksan, dengan dosis $15 \mathrm{gram} / \mathrm{g}$ BB yang merupakan dosis optimal dalam menurunkan kadar Glukosa dan Kadar MDA. 


\section{DAFTAR PUSTAKA}

American Diabetes Association.,2015. Physical Activity/ Exercise and Diabetes. Diabetes care 26 ( suppl 1 ) : 6269

Dipiro J.T., Talbert R,L, Yee G.C., Matzke G.R., wells B.G., and Posey L.M. 2015. Pharmachoterapy : A Patophysiologic Apporoach, 9 th $^{\text {th }}$ Edition. Mc Graw Hill, New York.

Dawiyah.2012. Uji Aktivitas Antioksidan Ekstrak Etanol Daun Beruwas Laut ( Scaevola taccada ( Gaertn)Roxb. Pada tikus ( Rattus norvegicus ) yang diinduksi Aloksan dengan parameter MDA. Makassar : Universitas Muslim Indonesia

Fitriana, L, Wijayanti, A.D., Sari,.W., Satria, R.G.D, Setiawan, D.C.B, Fibrianto, Y,H., Nugroho, W.S. 2017. Levels of malondialdehyde in type 2 Diabetes Melitus Induced Mesenchymal Stem. Cell Conditioned Media. Acta Veterianaria Indoeneisa. Vol 5, No 1 : 2936.

Hartono Rudy, Agustian Ipa, Aswita Amir, Adryani Adam, Rusli, Sudirman Katu, 2019. Lactobacillus casei strain shirota: Overview of blood sugar levels and blood fat from children obesity and Fatting. IJPHRD Indian Journal of Public Health Research and Development 10(8):2188.

Hartono Rudy, Bambang Wirjatmadi, Yoes Prihatna Dachlan, 2017. Improved

Immunity Elderly after Receiving Zinc. Dama International Journal of Researchers (DIJR), ISSN: 23436743.

Hasan, M, Khan, M.I., Umar, B.U., and Sedeque, M. 2013. Comparative study of effect of ethanolic of Swietenia Mahagoni seeds with rosiglitazone on Experimentally induced Diabetes Melitus in Rats. Faridpur Med. Coll. J. N0 39, p 610.

Preedy, V.R., Watson, R.R., and Patel, V.B, 2011. Nuts and Seeds in Health and Disease Prevention. United Kingdom : Acedemic Press.

Sumekar, W, D. dan Fauziah, S, 2016. Efektivitas Biji Mahoni ( Swietenia mahagoni) sebagai Pengobatan Diabetes Melitus Vol. 5.Fakultas Kedokteran, Universitas Lampung.

Tangvarasittichal S, Poonsub P, Tangvarasittichal $\mathrm{O}$, Sirigulsatein $\mathrm{V}$. 2014. Serum level of malondialdehyde in type 2 diabetes melitus Thai subjects. Siriraj Medicine Journal 61:20 23.

Tiwari BK., Pandey KB, Abidi AB, Rizvi SI. 2013. Marker oxidative stress during diabtes meitus. Journal of biomarkers volume $2013: 378790, p 18$.

Werdhasari, Asri. 2014. Peran Antioksidan Bagi KesehatanPusat Biomedis dan Teknologi Dasar Kesehatan. Balitbangkes, Kemenkes RI : Naskah Asli 